\title{
(2) OPEN ACCESS \\ Role reconfiguration: what ethnographic studies tell us about the implications of technological change for work and collaboration in healthcare
}

\author{
Heloise Agreli, ${ }^{1}$ Ruthanne Huising, ${ }^{1}$ Marina Peduzzi ${ }^{2}$
}

\begin{abstract}
- Additional material is published online only. To view, please visit the journal online (http://dx.doi.org/10.1136/ leader-2020-000224).
\end{abstract}

Research Center for Work Technology and Organization, Emlyon Business School, Ecully, Rhône-Alpes, France ${ }^{2}$ Department for Professional Guidance, School of Nursing, University of Sao Paulo, Sao Paulo, São Paulo, Brazil

\section{Correspondence to} Dr Heloise Agreli, Emlyon Business School, 69130 Ecully, Rhône-Alpes, France; agreli@em-Iyon.com

Received 19 February 2020 Revised 23 November 2020 Accepted 20 January 2021 Published Online First 28 April 2021
Check for updates

(C) Author(s) (or their employer(s)) 2021. Re-use permitted under CC BY-NC. No commercial re-use. See rights and permissions. Published by BMJ.

To cite: Agreli $H$, Huising $R$, Peduzzi M. BMJ Leader 2021;5:134-141.

\section{ABSTRACT}

New technologies including digital health and robotics are driving the evolution of healthcare. At the same time, healthcare systems are transitioning from a multiprofessional model approach of healthcare delivery to an interprofessional model. The concurrence of these two trends may represent an opportunity for leaders in healthcare because both require renegotiation of the complex division of work and enhanced interdependency. This review examines how the introduction of new technologies alters the role boundaries of occupations and interdependencies among health occupations. Based on a scoping review of ethnographic studies of technology implementation in a variety of contexts (from primary care to operating room) and of diverse technologies (from health informatics systems to robotics), we develop the concept of role reconfiguration to capture simultaneous adjustments of multiple, interdependent roles during technological change. Ethnographic and qualitative studies provide rich, detailed accounts of what people actually do and how their work and role is changed (or not) when a new technology arrives. Through a synthesis of these studies, we develop a typology of four types of role reconfiguration: negotiation, clarification, enlargement and restriction. We discuss leadership challenges in managing role reconfiguration and formulate four leadership priorities. We suggest that leaders: redesign roles proactively, paying attention to interdependencies; offer opportunities for collective learning about new technologies; ensure that knowledge of new technologies is distributed across roles and prepare to address resistance.

\section{BACKGROUND}

New technologies including digital health and robotics are among the factors driving the evolution of healthcare. The integration of digital health and robotics into health services is expected to lead to improvements in medical diagnosis, prevention and treatment of diseases, surgical interventions and long-term care. Digital health is expected to promote effective and automated work management processes. Innovations in the field of robotics offer a wide range of applications in healthcare with the potential to make medical procedures safer and more cost effective. ${ }^{1}$ The promise of vast new efficiencies afforded by health technologies has attracted interest from both health systems, overwhelmed by the increasing complexity and costs of care, ${ }^{2}$ and technology companies worldwide. As a result, the rapid adoption of digital health and robotic technologies is predicted. ${ }^{3}$

At the same time, healthcare systems are attempting to transition from a multiprofessional approach to healthcare delivery to an interprofessional approach. This shift is intended to refocus the organisation and management of work away from each professional group and towards interprofessional teams. The interprofessional model aims to improve team dynamics and processes, thus enhancing collaboration among professional groups by developing shared goals, clear team roles and integrated work practices. ${ }^{4}$ This approach is promoted as a means of better managing the ever-growing complexity of delivering healthcare and improving its effectiveness. ${ }^{5-7}$

The concurrence of these two trends may represent an opportunity for leaders because both challenges require renegotiating the complex division of work in healthcare and increasing collaboration among professional groups. We draw on ethnographic studies of technological change in healthcare settings to understand the implications of technological change for work roles and collaboration. New technologies create new tasks, automate or eliminate established tasks and shift tasks across professional groups, requiring that workers develop new skills and knowledge, accept changes to their job role and work with others in new ways. These disruptions usually create direct effects for two or more professional groups and create indirect effects for adjacent professional groups. Overall technological change generates role-reconfiguration adjustments in boundaries ${ }^{8}$ across multiple, interdependent roles. We synthesise findings about role reconfigurations from social sciences and health services. These findings suggest how leaders can trace and anticipate role reconfigurations in a way that supports technological change in healthcare. Studies of technological change offer valuable insights about the intended and unintended consequences of integrating a new technology ${ }^{8}$ in interprofessional healthcare teams.

\section{METHODS}

Design

We conducted a scoping review to systematically synthesise the findings of ethnographic studies of the implications of technological change for work and roles in healthcare. We selected topically relevant studies that employed ethnographic methods. Ethnographic studies provide detailed empirical observations about the work done, including collaboration and communication patterns, the interpretations and meanings of the work (from the workers' perspective) and the use of technologies (new and old). Given this, ethnographic studies are most appropriate for understanding how the integration of new technologies changes what workers do, how they do it and with whom they collaborate. While discourse studies of new technologies, and adoption, and interviews and surveys to change adoption are extremely valuable, they do not 
Table 1 Inclusion and exclusion criteria

\begin{tabular}{ll}
\hline Inclusion criteria & Exclusion criteria \\
\hline $\begin{array}{l}\text { Population: healthcare professionals and } \\
\text { other professionals involved in the provision } \\
\text { or management of healthcare service } \\
\text { (including administrative staff, managers, } \\
\text { medical directors). }\end{array}$ & \\
$\begin{array}{l}\text { Intervention: use and/or implementation of } \\
\text { health technologies (robots, CT scanners, }\end{array}$ & $\begin{array}{l}\text { Where the technology is treated as a type } \\
\text { of knowledge or as soft technologies such } \\
\text { telemedicine) with interdependent users. } \\
\text { as new skills. } \\
\text { Description of implementation or use of } \\
\text { a new technology that does not involve } \\
\text { interdependent users. }\end{array}$ \\
& $\begin{array}{l}\text { Perceptions of new health technologies/ } \\
\text { technological features without a description } \\
\text { of change processes and the implications for } \\
\text { work and roles. }\end{array}$ \\
$\begin{array}{ll}\text { Study type: qualitative studies that collected } \\
\text { data in interviews, observations, observation } \\
\text { of video consultations, focus groups and } \\
\text { document analysis. Qualitative reporting }\end{array}$ & $\begin{array}{l}\text { Opended user's assessment. } \\
\text { with in-depth description of interpretative } \\
\text { findings. }\end{array}$ \\
\hline
\end{tabular}

track and examine change at the level of daily work and interactions. This is in part because of the level and unit of analysis employed and also because we know that formal definitions of roles and verbal accounts of roles, detached from their doing, do not correspond accurately with what people do at work. ${ }^{9}$ Overall, we focused our review on relevant papers most likely to facilitate the development of new understanding of how technology changes work, roles and collaboration.

\section{Criteria for including studies}

The inclusion and exclusion criteria are shown in table 1. We identified ethnographic studies investigating the introduction of new technologies across different healthcare settings (from primary care to operating room) and of diverse technologies with interdependent

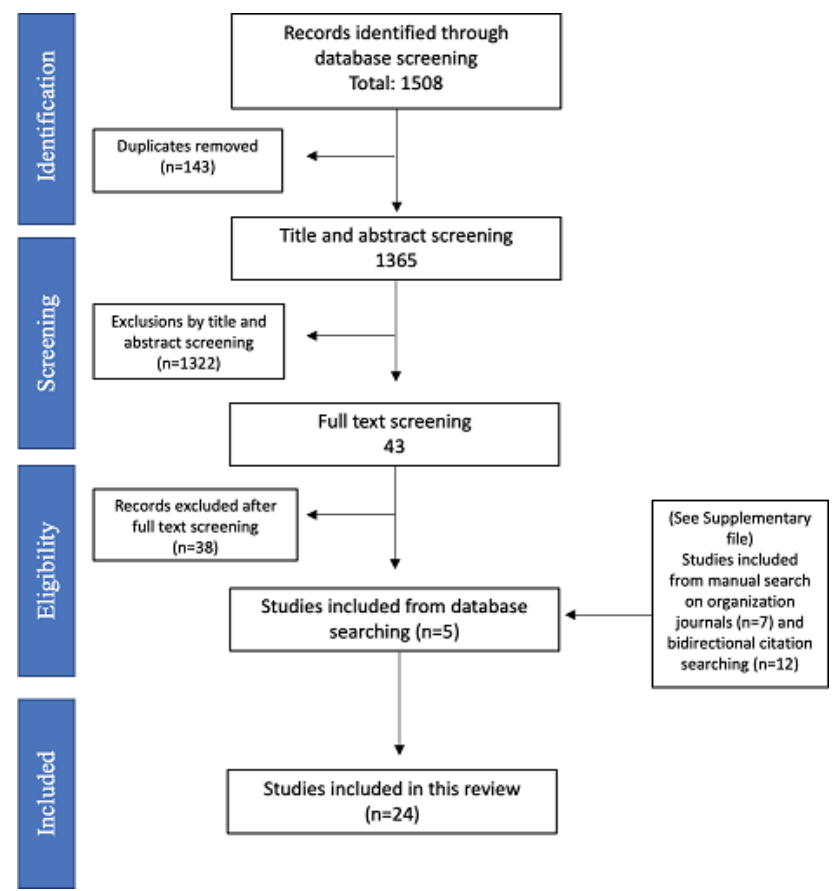

Figure 1 PRISMA flowchart of identification and inclusion of studies. PRISMA, Preferred Reporting Items for Systematic Reviews and MetaAnalyses. users (from health informatics systems to robotics). We excluded studies that treated technology as a type of knowledge or as soft technologies such as new skills.

\section{Search strategy}

Initial searches in peer-reviewed health science journals were conducted in June 2019 (figure 1). The search was limited to a 2-year period (2017-2019) because of the growing interest in health technologies and studies related to this thematic. The goal was to identify the most recent publications in high-ranking, peer-reviewed health science journals. The full list of search terms was built iteratively and informed by the results in each database (see online supplemental file 1).

\section{Organisational journals}

The references of retrieved articles indicated organisation journals as a useful source for ethnographies of work. A manual search of organisation journals was undertaken (see online supplemental file 2). No date restrictions were applied to organisation journals because there were few studies related to our search terms published between 2017 and 2019.

\section{Bidirectional citation chasing}

We used a bidirectional citation chasing approach to generate a full list of qualitative references describing the implications of technological change for work and roles in healthcare (see online supplemental file 3). The initial references in this instance were the five papers sourced in the database search ${ }^{810-13}$ and the seven papers from the manual search. ${ }^{14-20}$ Through the citation chasing process, 12 additional papers were identified. ${ }^{21-32}$

\section{Data analysis}

We used Nvivo V.11 software to organise and support our analysis. Through open coding and constant comparison, we inductively developed the role-reconfiguration concepts presented below. The movement between the codes and the eventual concepts was iterative, meaning that we wrote, developed schematics and worked with the codes in numerous ways until we identified and articulated patterns across the literature. Full details of data extraction can be seen in tables 2 and 3.

\section{RESULTS}

\section{Role reconfiguration}

There is consensus across the studies that technologies serve as an occasion for role reconfiguration. The implementation of new technologies depends on changes in the tasks, interactions and knowledge of professional groups. Our analysis reveals four themes pertaining to the reconfiguration of roles-negotiation, clarification, enlargement and restriction-which relate to authority and knowledge structures as depicted in figure 2. In the context of professions, authority is the right to issue commands related to a set of tasks. Members of a profession claim authority when their profession has the regulatory right or most appropriate expertise to address a social problem. ${ }^{33}$ The $y$-axis shows professions distributed across this range of authority, highlighting medical dominance-physicians' authority over other professions - as the traditional organising principle in healthcare delivery. The $\mathrm{x}$-axis refers to knowledge about how to apply and monitor them in healthcare settings.

Overall, when a new technology is implemented, roles tend to be altered according to their degree of professional authority and their knowledge of the new technology. Roles may be enlarged or restricted, clarified or negotiated. Those with high degree of authority - physicians - have the privilege of negotiating their roles 
Table 2 Data extraction table: characteristics of included studies

\begin{tabular}{|c|c|c|c|c|c|}
\hline Reference & $\begin{array}{l}\text { Country and } \\
\text { research setting }\end{array}$ & New technology & Methods & Study participants & Key findings \\
\hline $\begin{array}{l}\text { Morland and } \\
\text { Pettersen }\end{array}$ & Norway, hospitals & Speech recogniser & $\begin{array}{l}\text { Interviews, document } \\
\text { analysis, observations }\end{array}$ & Physicians and secretaries & $\begin{array}{l}\text { Physicians diversely adjust to the new technology. In the } \\
\text { translation process, powerful actors (physicians) influence } \\
\text { outcome of changes and thus they affect the effectiveness of the } \\
\text { change initiatives. }\end{array}$ \\
\hline $\begin{array}{l}\text { Bjørkquist, Forss } \\
\text { and Samuelsen }{ }^{10}\end{array}$ & $\begin{array}{l}\text { Norway, multiple } \\
\text { settings }\end{array}$ & $\begin{array}{l}\text { Telecare/ electronic device: } \\
\text { personal alarms }\end{array}$ & Interviews, group interviews & $\begin{array}{l}\text { Front-line staff members middle } \\
\text { managers }\end{array}$ & $\begin{array}{l}\text { The new technology does not simplify collaboration or solve } \\
\text { collaboration challenges; it just limits information to written form. }\end{array}$ \\
\hline Swinkels et al ${ }^{11}$ & $\begin{array}{l}\text { Netherlands, } \\
\text { primary healthcare } \\
\text { services }\end{array}$ & eHealth & Interviews and focus groups & $\begin{array}{l}\text { Healthcare professionals and } \\
\text { patients }\end{array}$ & $\begin{array}{l}\text { For sustainable use of eHealth, primary healthcare professionals } \\
\text { need to be reinforced in their management. }\end{array}$ \\
\hline Tintorer et al ${ }^{12}$ & $\begin{array}{l}\text { Spain, primary } \\
\text { healthcare services }\end{array}$ & $\begin{array}{l}\text { Virtual communities of } \\
\text { practice }\end{array}$ & $\begin{array}{l}\text { Descriptive-interpretative } \\
\text { qualitative study using focus } \\
\text { groups and interviews }\end{array}$ & $\begin{array}{l}\text { Physicians and nurse with } \\
\text { different positions within the } \\
\text { organisation (healthcare or } \\
\text { managerial) }\end{array}$ & $\begin{array}{l}\text { In order to make the most of its potential in terms of care and } \\
\text { education, organisational changes are required to foster greater } \\
\text { use. }\end{array}$ \\
\hline Randell et al ${ }^{13}$ & England, hospitals & Robot-assisted surgery & Realist interview study & $\begin{array}{l}\text { Surgeons, surgical trainees, } \\
\text { theatre nurses, operating } \\
\text { department practitioners and } \\
\text { anaesthetists }\end{array}$ & $\begin{array}{l}\text { Motivation among team members to persist with robot-assisted } \\
\text { surgery can be achieved without involvement in the initial } \\
\text { decision to purchase a robot, but training that enables team } \\
\text { members to feel confident as they take on the new tasks is } \\
\text { essential. }\end{array}$ \\
\hline Beane $^{14}$ & USA, hospitals & Robot-assisted surgery & Observations and interviews & $\begin{array}{l}\text { Surgeons, nurses, scrubs, } \\
\text { residents, theatre nurses and } \\
\text { anaesthetists }\end{array}$ & $\begin{array}{l}\text { The practice of robotic surgery greatly limited trainees' role in the } \\
\text { work, making approved methods ineffective. Learning surgery in } \\
\text { this context required 'shadow learning': an interconnected set } \\
\text { of norm-challenging and policy-challenging practices enacted } \\
\text { extensively, opportunistically and in relative isolation that } \\
\text { allowed only a minority of robotic surgical trainees to come to } \\
\text { competence. }\end{array}$ \\
\hline Black et $a l^{15}$ & USA, hospitals & CT scanning & $\begin{array}{l}\text { Interpretative qualitative } \\
\text { research }\end{array}$ & Radiologists and technologists & $\begin{array}{l}\text { A balance of expertise across occupational boundaries in } \\
\text { operating the technology creates a pattern in which the benefits } \\
\text { of the new technology are likely to be realised most rapidly. }\end{array}$ \\
\hline Edmonson et a $\left.\right|^{16}$ & USA, hospitals & $\begin{array}{l}\text { Technology for cardiac } \\
\text { surgery }\end{array}$ & Observations and interviews & $\begin{array}{l}\text { Operating room team, hospital } \\
\text { administrators, cardiologists, } \\
\text { intensive care unit nurses and } \\
\text { general unit (floor) nurses }\end{array}$ & $\begin{array}{l}\text { There is a positive influence of psychological safety on collective } \\
\text { team learning and establishing new routines during technology } \\
\text { implementation. }\end{array}$ \\
\hline Barret et $a l^{17}$ & $\begin{array}{l}\text { England, hospital } \\
\text { pharmacies }\end{array}$ & $\begin{array}{l}\text { Pharmaceutical-dispensing } \\
\text { robot }\end{array}$ & Observations and interviews & $\begin{array}{l}\text { Pharmacists, technicians, } \\
\text { assistants, administrative } \\
\text { workers }\end{array}$ & $\begin{array}{l}\text { Engagement with robots over time reconfigured boundary } \\
\text { relations among the three occupational groups, with important } \\
\text { and contradictory consequences for the pharmacy workers' skills, } \\
\text { status and visibility. }\end{array}$ \\
\hline Gherardi $^{18}$ & $\begin{array}{l}\text { Italy, telecardiology } \\
\text { centres }\end{array}$ & Telecardiological consultancy & Observations and interviews & $\begin{array}{l}\text { General practitioners, } \\
\text { cardiologists }\end{array}$ & $\begin{array}{l}\text { As telecardiology comes into use, it is inscribed more in the social } \\
\text { practice of reassurance than in the medical one of preventing and } \\
\text { dealing with emergencies. }\end{array}$ \\
\hline Korica and Moloy ${ }^{19}$ & England, hospitals & Telemedicine & Interviews & Senior surgeons & $\begin{array}{l}\text { The article draws attention to how new technologies provide } \\
\text { occasions for the evaluation of existing intraprofessional and } \\
\text { interprofessional relationships and professional identity as a } \\
\text { whole. }\end{array}$ \\
\hline Nicolini ${ }^{20}$ & $\begin{array}{l}\text { Italy, telecardiology } \\
\text { call centres }\end{array}$ & Telemedicine & Observations and interviews & $\begin{array}{l}\text { Managers, cardiologists, } \\
\text { nurses, technicians, general } \\
\text { practitioners of monitored } \\
\text { patients }\end{array}$ & $\begin{array}{l}\text { The study argues that in order to cope with the expansion of their } \\
\text { activity after implementation of telecardiological consultancy, } \\
\text { practitioners had to face three main practical problems: they } \\
\text { had to redistribute their work and tasks among human and } \\
\text { non-human elements, they had to reframe the ways in which the } \\
\text { activity was made accountable and they had to reconfigure the } \\
\text { relationships between all those involved. }\end{array}$ \\
\hline Segar et $\left.a\right|^{21}$ & $\begin{array}{l}\text { England, telehealth } \\
\text { call centres }\end{array}$ & Telehealth & Interviews and observations & $\begin{array}{l}\text { Telehealth nurse care managers, } \\
\text { practice nurses and general } \\
\text { practitioners }\end{array}$ & $\begin{array}{l}\text { 'Commissioners and professionals who wish to integrate } \\
\text { telehealth innovations into existing primary care services for LTCS } \\
\text { need to pay attention to how changes in service delivery impact } \\
\text { on professionals' perceptions of their role and identity. Without } \\
\text { this, the introduction of telehealth may lead to resistance and } \\
\text { inter- and intra-professional rivalries' (p. 612). }\end{array}$ \\
\hline Gagnon et $a l^{22}$ & Canada, hospital & Telehealth & Interviews & $\begin{array}{l}\text { Medical directors, director's } \\
\text { assistant, administrators, } \\
\text { physicians }\end{array}$ & $\begin{array}{l}\text { The study highlights the relevance of considering the } \\
\text { characteristics and the dynamics of healthcare organisations at } \\
\text { each stage of telehealth implementation in order to take their } \\
\text { specific needs into account. }\end{array}$ \\
\hline Pelikan et $a l^{23}$ & USA, hospital & Surgical robot & interviews and video data & $\begin{array}{l}\text { Surgical staff (surgeons, } \\
\text { residents, student, first } \\
\text { assistants, anaesthesiologist, } \\
\text { scrub nurses, circulator nurses } \\
\text { and charge nurse) }\end{array}$ & $\begin{array}{l}\text { Description of new forms of physical, cognitive and affective } \\
\text { distance associated with tele-operated robotic surgery and the } \\
\text { effects of teleoperated robotic on power distribution, practice and } \\
\text { collaborative experience within the surgical team. }\end{array}$ \\
\hline $\begin{array}{l}\text { Stevens and van } \\
\text { Schaik }^{24}\end{array}$ & $\begin{array}{l}\text { Netherlands, } \\
\text { hospitals }\end{array}$ & Endovascular techniques & Interviews & $\begin{array}{l}\text { Surgical staff (surgeons, } \\
\text { anaesthesiologist, scrub nurses, } \\
\text { radiologist) }\end{array}$ & $\begin{array}{l}\text { Relational and cognitive embeddedness factors support team } \\
\text { learning, which in turn enables the team to achieve its self-set } \\
\text { goals of treating more patients, offering more tailor-made care } \\
\text { and providing endovascular treatment in emergency situations. }\end{array}$ \\
\hline Petrakaki et al ${ }^{25}$ & England, hospital & Electronic patient record & $\begin{array}{l}\text { Interviews and document } \\
\text { analysis }\end{array}$ & $\begin{array}{l}\text { Healthcare professionals, } \\
\text { managers and members of the } \\
\text { technical team }\end{array}$ & $\begin{array}{l}\text { Identical technologies afford different changes in professional } \\
\text { roles and structures depending on how technology is interpreted } \\
\text { in the context of its use. }\end{array}$ \\
\hline $\begin{array}{l}\text { Petrakaki and } \\
\text { Kornelakis }^{26}\end{array}$ & $\begin{array}{l}\text { England, NHS } \\
\text { trusts }\end{array}$ & Electronic patient record & $\begin{array}{l}\text { Interviews and document } \\
\text { analysis }\end{array}$ & $\begin{array}{l}\text { Healthcare professionals, } \\
\text { managers and members of the } \\
\text { technical team }\end{array}$ & $\begin{array}{l}\text { 'The implication of technology in professional work conditions } \\
\text { processes of task routinization that constrain autonomy, and } \\
\text { enables reallocation of discretion between professional groups' } \\
\text { (p. 223). }\end{array}$ \\
\hline
\end{tabular}




\begin{tabular}{|c|c|c|c|c|c|c|c|c|}
\hline Reference & $\begin{array}{l}\text { Country and } \\
\text { research setting }\end{array}$ & \multicolumn{2}{|l|}{ New technology } & \multicolumn{2}{|c|}{ Methods } & \multicolumn{2}{|c|}{ Study participants } & Key findings \\
\hline Mathieu-Fritz et $a l^{27}$ & France, hospital & \multicolumn{2}{|l|}{ Telemedicine } & \multicolumn{2}{|c|}{$\begin{array}{l}\text { Observation of video } \\
\text { teleconsultations and } \\
\text { interviews }\end{array}$} & \multicolumn{2}{|c|}{$\begin{array}{l}\text { Dermatologists, surgeons, } \\
\text { neurologists, geriatricians, } \\
\text { cardiologists and speech } \\
\text { therapists }\end{array}$} & $\begin{array}{l}\text { Changes in interactions observable in teleconsultations } \\
\text { encourage changes in terms of professional practices themselves. }\end{array}$ \\
\hline Meyer and Paré28 & $\begin{array}{l}\text { Canada, } \\
\text { telemedicine } \\
\text { centres }\end{array}$ & \multicolumn{2}{|c|}{$\begin{array}{l}\text { Telemedicine/intraoperative } \\
\text { consultations }\end{array}$} & \multicolumn{2}{|c|}{ Observations and interviews } & \multicolumn{2}{|c|}{$\begin{array}{l}\text { Technologists, surgeons and } \\
\text { pathologists }\end{array}$} & $\begin{array}{l}\text { After implementation of the new technology, accountability } \\
\text { became less collective and more individual and contractual, } \\
\text { resulting in more marked boundaries between professional } \\
\text { groups. }\end{array}$ \\
\hline Sergeeva et $a l^{29}$ & $\begin{array}{l}\text { Netherlands, } \\
\text { hospital }\end{array}$ & \multicolumn{2}{|l|}{ da Vinci robot } & \multicolumn{2}{|c|}{ Observations and interviews } & \multicolumn{2}{|c|}{ s Surgical staff } & $\begin{array}{l}\text { The robot brings a new spatial distribution of roles and activities } \\
\text { next to and away from the patients' body, transforms work } \\
\text { relations and triggers a new order of space use, yielding expertise } \\
\text { movement and altering visibility. }\end{array}$ \\
\hline Bergey et $a l^{30}$ & USA, hospitals & \multirow{2}{*}{\multicolumn{2}{|c|}{$\begin{array}{l}\text { Health information } \\
\text { technology }\end{array}$}} & \multicolumn{2}{|c|}{ Observations and interviews } & \multicolumn{2}{|c|}{ NS Nursing team } & $\begin{array}{l}\text { The implementation of health information technology generated } \\
\text { significant reconfigurations of work practices at the expense } \\
\text { of nurse-patient interaction. Following such changes, nursing } \\
\text { leadership described a realignment in staffing in order to have } \\
\text { more versatile staff and task delegation of largely invisible work } \\
\text { to unit clerks. }\end{array}$ \\
\hline Barley $^{31}$ & USA, hospitals & & & \multicolumn{2}{|c|}{ Observations and interview } & \multicolumn{2}{|c|}{ vs Radiologists and technologists } & $\begin{array}{l}\text { Technology can alter institutionalised roles and patterns of } \\
\text { interaction at work. }\end{array}$ \\
\hline \multicolumn{2}{|l|}{ Reference } & $\begin{array}{l}\text { Negotiating } \\
\text { roles }\end{array}$ & \multicolumn{2}{|c|}{$\begin{array}{l}\text { Clarifying } \\
\text { roles }\end{array}$} & $\begin{array}{l}\text { Enlarging } \\
\text { roles }\end{array}$ & $\begin{array}{l}\text { Restricted } \\
\text { roles }\end{array}$ & \multicolumn{2}{|c|}{ Leadership priorities during periods of technological change } \\
\hline \multicolumn{2}{|c|}{ Morland and Pettersen ${ }^{8}$} & $\mathrm{x}$ & & & & $\mathrm{x}$ & \multicolumn{2}{|c|}{ Expect and address resistance } \\
\hline \multicolumn{2}{|c|}{ Bjørkquist, Forss and Samuelsen ${ }^{10}$} & & & & & & \multicolumn{2}{|c|}{$\begin{array}{l}\text { Expect and address resistance; offer collective opportunities to learn about the } \\
\text { new technology }\end{array}$} \\
\hline \multicolumn{2}{|l|}{ Swinkels et $a l^{11}$} & & & & & & \multicolumn{2}{|c|}{ Distribute expertise of the new technology } \\
\hline \multicolumn{2}{|l|}{ Tintorer et al $l^{12}$} & & & & & & Expect and addres & s resistance \\
\hline Randell et $a l^{13}$ & & & & & & & $\begin{array}{l}\text { Proactively redesi } \\
\text { learn about the } n \in\end{array}$ & $\begin{array}{l}\text { an roles and interdependencies; offer collective opportunities to } \\
\text { w technology }\end{array}$ \\
\hline Beane $^{14}$ & & & & & & $\mathrm{x}$ & & \\
\hline Black et $a l^{15}$ & & $\mathrm{x}$ & & & & & Offer collective op & portunities to learn about the new technology \\
\hline Edmonson et al ${ }^{16}$ & & $\mathrm{x}$ & & & & & $\begin{array}{l}\text { Offer collective op } \\
\text { address resistance }\end{array}$ & portunities to learn about the new technology; expect and \\
\hline Barret et $a l^{17}$ & & & & & $\mathrm{x}$ & $\mathrm{x}$ & & \\
\hline Gherardi ${ }^{18}$ & & & & & & & Expect and addres & s resistance \\
\hline Korica and Moloy ${ }^{19}$ & & $x$ & & & & & & \\
\hline Nicolini ${ }^{20}$ & & $x$ & $x$ & & & & Offer collective op & portunities to learn about the new technology \\
\hline Segar et $a^{P^{21}}$ & & & & & $x$ & & Expect and addres & s resistance \\
\hline Gagnon et $a l^{22}$ & & & & & & & Expect and addres & s resistance \\
\hline Pelikan et $a l^{23}$ & & & $x$ & & & & & \\
\hline Stevens and van $\mathrm{Scl}$ & haik $^{24}$ & & & & & & Offer collective op & portunities to learn about the new technology \\
\hline Petrakaki et $a l^{25}$ & & & $x$ & & & & & \\
\hline Petrakaki and Korne & elakis $^{26}$ & & & & & & Expect and addres & s resistance \\
\hline Mathieu-Fritz et al ${ }^{27}$ & & $x$ & & & & & & \\
\hline Meyer and Paré 28 & & $x$ & & & & & & \\
\hline Sergeeva et $a l^{29}$ & & & & & $x$ & $x$ & & \\
\hline Bergey et $\left.a\right|^{30}$ & & $\mathrm{x}$ & & & $x$ & $\mathrm{x}$ & & \\
\hline Barley $^{31}$ & & $\mathrm{x}$ & & & & & Distribute expertis & e of the new technology \\
\hline Burri $^{32}$ & & $x$ & & & & & & \\
\hline
\end{tabular}

in ways that may reduce differentiation among medical specialties affected by the new technology. Nurses and allied professions tend to have their roles clarified and enlarged by the new technologies. Workers out of the scope of clinical practice, but who offer administrative support to clinical work (ie, secretaries, clerks) or support medical practice as part of a learning process (ie, residents), often have their roles restricted.

When a new technology is introduced, knowledge of this technology - knowledge about how to apply, monitor, adjust and evaluate it-allows those who develop this knowledge to have a better control over their work. Often this leads to an expansion of their role, creating new dynamics with those working around them who do not have knowledge of the technology. The knowledge of the new technology seems to be the main force that triggers enlargement of roles. We describe each form of role reconfiguration ${ }^{i}$ and high-

${ }^{\mathrm{i}}$ The patterns that we identify are roughly consistent with the polarisation effects of technologies on skill demand and wages identified by economists. (Autor, D. H., Levy, F., \& Murnane, R. J. (2003). The skill content of recent technological change: An empirical exploration. The Quarterly Journal of Economics, 118(4), 1279-1333; and Autor, D. H., Katz, L. F., \& Kearney, M.S. (2006). The polarization of the US labor market. The American Economic Review, 96(2), 189-194). However, our analysis reveals the mechanisms and dynamics involved in 


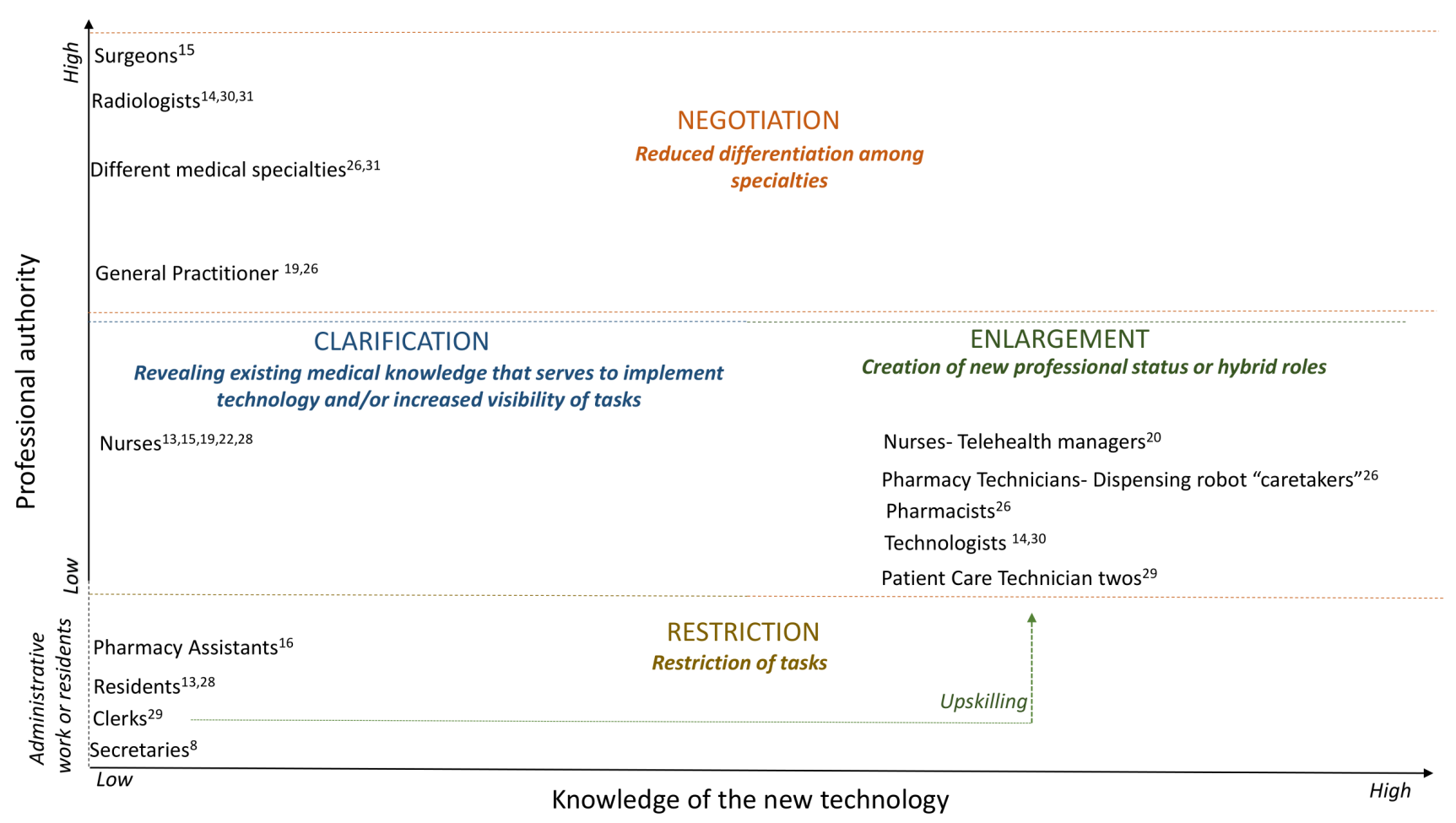

Figure 2 Model outlining the four types of role reconfiguration.

light leadership priorities during technological change to ensure the successful integration of digital health and robotics into interprofessional health services.

\section{Negotiating roles}

Physicians, because of their professional authority, are able to interfere in the successful implementation of new technologies. This occurs when physicians continue to work as usual around the new technology rather than altering their work practices and clinical interactions with other team members, in relation to the new technology. A comparative case analysis of the implementation of a new cardiac technology across 16 American hospitals found that successful implementation occurred when the healthcare teams reconsidered the way they worked, shifting tasks and changing their coordination practices. ${ }^{16}$ Because of their professional authority, physicians can be central in leading and directing such changes in teams. When physicians do not integrate new technologies into their work routines, those working around them are less likely or able to do so.

Given this, the technological implementation process relies on physicians (ie, surgeons, radiologists, general practitioners and other medical specialists) to renegotiate the boundaries of their roles within their team. ${ }^{1928}$ A central part of this negotiation is accepting that there is a new distribution of expertise or 'who knows what' on the team. Except in the case of robotic surgery, technologies are often known and controlled by technicians or members on the team other than physicians. This means that physicians have to rely on and coordinate with members of the team in a new way that often alters the distribution of authority and thus the power differential among

technology implementation at the level of role systems rather than individual jobs in isolation. This lens indicates that there are ways to implement such technologies to complement all roles in the system rather than simply upskilling and deskilling. This requires engaged and thoughtful leadership. members of the team. ${ }^{28}$ The introduction of new technologies requires that physicians develop expertise about how to work with the new technology or accept the value of this expertise in others.

Barley $^{31}$ and Black et al ${ }^{15}$ discuss how CT scans made the expertise of radiologists and technicians inseparable. The expertise needed to conduct a CT scan and the expertise needed to interpret the images were no longer clearly defined and separable, as they were with X-ray technology. ${ }^{15} 31$ Radiologists had to change the way they worked with technicians, becoming more interdependent and collaborative with technicians, thus shifting the boundaries of their role and the technician role. ${ }^{32}$ Similarly, a new technology for cardiac surgery increased communication and interdependence across professions, changing the team member's task and blurring the former hierarchy of team roles. ${ }^{16}$ By changing the distribution of expertise and tasks, technological change shifts power relations among team members. ${ }^{20}$ Such shifts often require physicians to relinquish the traditional notion that they are the most knowledgeable member of the team, accepting that knowledge of how to use new technologies and interpret their outputs is integral to medical care and sharing authority with those who have such expertise.

\section{Clarifying roles}

Nurses and allied health professionals often possess unnoticed medical knowledge. These practitioners learn by working closely with physicians in daily clinical practice, developing knowledge and skills that are not formally recognised by the organisation. The introduction of new technologies often reveals and clarifies the actual tasks nurses perform and the related medical skills and knowledge required to perform these tasks. ${ }^{26}$ In doing so, the technology also reveals overlaps in task, skills and knowledge among members of the team. For example, the introduction of telemedicine enabled managers to recognise the knowledge that nurses had in handling specific drugs-a task previously reserved only for physicians. ${ }^{20}$ The introduction of robots into operating theatres has revealed the latent 
knowledge and skills of nurses who are now responsible for the direct physical manipulation of instruments through the trocars inside the body of the patient. They did not perform these tasks prior to the introduction of the robots but had the knowledge of how to do it because they had observed and assisted surgeons doing it for years. ${ }^{29}$

Often the nurses' unacknowledged knowledge and skills are revealed by the spatial and temporal separations of the work of nurses and physicians created by new technologies. As nurses work asynchronously and at a distance from physicians, it is possible to observe their skills and knowledge in a new way. Pelikan et al $^{23}$ show how a tele-operated surgical robot reconfigured teamwork. As the surgeon moved from the patient's side, registered nurses took their place, supporting the surgeon by controlling the suction machine and changing the instruments. These nurses already had the skills to act as first assistants, mediating the interaction between nurses and surgeons during the surgery.

The recognition of the actual tasks, skills and knowledge of nurses is made possible by the introduction of new technologies. At the same time, the smooth implementation of these technologies is made possible because nurses have this unacknowledged experience and related skills and knowledge. One of the important implications of role clarification is that it leads to role enlargement (discussed next). However, most studies show that the enlargement of nursing roles through additional tasks and responsibilities is not recognised by management and their organisations. Role clarification, without official enlargement of roles, enables minor changes in the control of medical techniques (ie, nurses controlling the suction machine, manipulating surgical trocars, triaging patients) but does not create changes in professional authority. When this happens, new technologies solidify the subordinate position of nurses. Despite clarifying their increased skills, knowledge and responsibilities, nurses are simply asked to do more for the same working conditions and employment relationships. ${ }^{27}$ We suggest that this is highly problematic from a number of perspectives and discuss how leaders can address this issue below.

\section{Enlarging roles}

Professions that are able to enlarge their roles during technological change have some degree of professional authority (ie, nurses, pharmacists) and develop knowledge and skills related to the use of the new technology. Hence, they have the opportunity to negotiate control over this new technology, and through this they enlarge their role or develop new hybrid roles. Segar $e t a^{21}$ describe how technological change provided a career change opportunity for nurses. Working with telehealth allowed nurses to move from 'hands on' nursing to telehealth managing. This enlarged role was considered by the nurses to be a less physically and emotionally demanding activity than nursing work. Barrett $e t$ al ${ }^{17}$ found that introduction of a dispensing robot in pharmaceutical work enabled enlargement of the technician's role in dispensing medications and provided technicians a more prestigious professional identity. Similarly, the dispensing robot provided pharmacists an enlargement of their role in patientcentred work and research, reasserting their privileged position in the pharmacy hierarchy. This was possible because the dispensing robot allowed pharmacists to maintain control of the dispensary at a distance and freed up their time to engage in other specific and more complex activities.

In these examples, nurses and technicians proactively became expert users of the technology, and in doing so they moved into new roles as telehealth managers ${ }^{21}$ or caretakers of the robot. ${ }^{17}$ Bergey et $a l^{30}$ describe how unit clerks experienced an enlargement of their roles following the implementation of a health information system. A new hybrid role was created combining basic patient-centred care responsibilities (ie, answering unit call lights) with user knowledge of a new health information technology.

\section{Restricted roles}

Healthcare roles with limited authority (eg, medical secretaries, clerks and in some cases medical residents) are often 'restricted' during the implementation of new technologies. These roles may be eliminated because of the automation of all tasks or deskilled because challenging tasks are automated or assigned to other roles. In the latter case, technological features allow those with superior authority to work with restricted help from assistants or residents. Opportunities to develop knowledge about the new technologies are often foreclosed to people in these roles. They may learn these new technologies informally on their own initiative. ${ }^{14}$

Examples of roles being restricted are numerous. The implementation of a pharmaceutical-dispensing robot limited the autonomous work of pharmacy assistants. ${ }^{17}$ Before implementation of the dispensing robot, assistants could work with little supervision from technicians or pharmacists. However, some robotic features reinforced the hierarchy of pharmaceutical work and the well-established distinctions between assistants and the other two occupational groups (technicians and pharmacists). Similarly, the introduction of a health information technology system reduced various tasks that clerks previously addressed, such as copying and entering orders. Unit clerks thus had less job security. ${ }^{30}$ Medical secretaries lost their jobs after implementation of a speech recogniser device, as their transcription services (their primary task) were no longer needed and the hospital used this restriction as an opportunity to pay for the new technology. ${ }^{8}$

When new technologies enlarge roles by shifting tasks down the chain of medical expertise, those in training - such as residentsmay find their roles restricted. For example, the adoption of roboticassisted surgery can trigger a shift of simpler tasks from surgeons to scrub nurses, limiting the opportunities the resident has to participate in their mentor's work. ${ }^{1429}$ The introduction of a robot in the operating room increased the physical distance between surgeon and other professions, a change that limited learning and teaching opportunities for residents. ${ }^{14}{ }^{29}$ Residents, who used to assist surgeons, have their role restricted in the surgical team, spending the majority of time watching the surgeon operate the robot, rather than participating. ${ }^{14}$

\section{Leadership priorities during periods of technological change}

Leaders appreciate the importance of actively managed technological change, guiding activities towards organisational goals and in alignment with organisational values. ${ }^{34} \mathrm{~A}$ key task for healthcare leaders is to recognise how roles may be reconfigured in the midst of technological change and to anticipate challenges inherent in role reconfigurations. Role negotiation, clarification, enlargement and restriction show how interdependent work around new technologies is restructured, often disrupting the established division of labour, including embedded knowledge and authority hierarchies. We suggest four ways that leaders can facilitate constructive role reconfiguration during periods of technological change.

\section{Proactively redesign roles and interdependencies}

Technological change requires that managers evaluate jobs and their design. In such evaluations, a task analysis of jobs prior to and following the implementation of a new technology can help assess the need for a redistribution of tasks across roles. This allows managers to identify the need for each form of role reconfiguration and to facilitate it. 
When technology clarifies roles, leaders face the decision of whether to formally recognise the formerly unrecognised skills, knowledge and tasks. This acknowledgement could take multiple forms including new job categories, titles and rewards. In situations where this acknowledgement is difficult or requires time, leaders may consider intermediate measures such as verbal and symbolic recognition. Failure to recognise gaps between actual and recognised work may lead to decreased motivation and cynicism. ${ }^{13}$ Another potential challenge, not explored in the literature, is the implications of such revelations for physicians. How do physicians experience passing off tasks, even mundane ones, to nurses? What is lost in the physicianclient relationship?

The elimination of roles and deskilling of roles due to technological change is an old story. ${ }^{35}$ However, the process through which roles are restricted and the unanticipated side effects are important to consider. In the case of automating the work of assistants and secretaries, healthcare organisations are at risk of losing long-term employees with significant organisational knowledge related to operating processes, legacy technologies and idiosyncratic people. ${ }^{36}$ This can be disruptive to operations. This is in addition to the well-known negative reverberations of lay-offs. ${ }^{37}$ Further, the restricting of some roles often means that other roles are being enlarged. The simultaneous enlargement of related roles should be recognised, and some amount of time and support is necessary for new tasks to be absorbed into other roles.

\section{Offer collective opportunities to learn about the new technology}

The studies we reviewed highlight the importance of collective learning as key to determining whether a technology takes hold or not. ${ }^{15} 1638$ This is important because new technologies tend to require improvements in interdependency and closer work between professions. ${ }^{10}{ }^{24}$ Moreover, for many technologies, new technical and social knowledge must be transferred to enable use. This transfer of knowledge, that is part of the role reconfiguration, is not a single act but discrete steps of enrolment, preparation, trial and reflection across professions. ${ }^{16}$ Collective opportunities to learn about the technology can enable health professionals to recombine their knowledge in a meaningful way during technological change ${ }^{131820}$ and allow professions to move to enlarge their roles. For those for whom a role enlargement is expected, the leadership challenge is to promote learning opportunities that open up possibilities for upskilled jobs in healthcare that might ultimately improve the quality of healthcare services.

\section{Distribute expertise of the new technology}

To help healthcare teams realise the benefits of a new technology, leaders can promote strategies to sustain the development of a balance of expertise across groups. Such a balance of expertise of the new technology should be a leadership priority, as it allows productive interactions between professions and sustains a collaborative pattern instead of fear and anxiety. ${ }^{15}$ Knowledge transfer and support from those with expertise in the new technology can facilitate its successful integration into daily work. ${ }^{11}$ If leaders do not encourage a balance of expertise, some professionals who know more than others about how to use the technology are likely to dominate the use of it, accumulating more knowledge of the new technology and reinforcing a pattern of professional dominance instead of collaboration. ${ }^{15} 31$ Furthermore, we argue that a balance of expertise could favour the observability attribute required for the diffusion of innovation. The observability is defined by Rogers as the 'degree to which the results of an innovation are visible to others'. It has been positively correlated with the rate of acceptance of a new technology. ${ }^{39}$ We believe that a shared understanding of the new technology and its potential results and benefits could motivate the adoption of an innovation across professional groups.

\section{Expect and address resistance}

The introduction of new technologies can open space for more interdependent work; however, this is more likely to happen when some professionals renegotiate their roles on the team, yielding their authority and adjusting their practice to support technological change. Leaders may want to include health professionals in the design and the implementation phases in order to design the functions of technologies and negotiate their roles. ${ }^{8}$ It is particularly important to plan how different professionals can recombine their work during technological change. ${ }^{4011}$ Moreover, by allowing participation of professionals in the design and implementation phases, leaders have the opportunity to discuss the benefits of new technology and negotiate changes in their expertise-based authority.

Professionals can be resistant to implement and have a negative outlook towards a new technology due to technology anxiety and fear that it can change the present work practices, ${ }^{22}{ }^{41} 42$ undermine professional roles ${ }^{21}$ and restrict their roles. Overall, leaders have to encourage all team members to articulate their concerns and be active in the change process. ${ }^{16}$ An open attitude from leadership is central to breaking down barriers to collaboration and can encourage the establishment of new ways of working together around the new technology. ${ }^{10}$

The literature also suggests that leaders handpick a team of professionals dedicated to piloting the technological change. ${ }^{1316}$ Randel et al. ${ }^{13}$ describe how a team selected by managers (to undertake technological training abroad) felt privileged and motivated to work to overcome the challenges of robot-assisted surgery, despite changes in their workload. Leadership can also ensure that professionals have more time in their working day to spend on the new technology. ${ }^{12}$

\section{CONCLUSION}

This review shows the role-reconfiguration effects of technological change. We identify four types of role reconfiguration: negotiation, clarification, enlargement or restriction. Our findings emphasise the importance of leadership during periods of technology change. Leaders should anticipate and acknowledge role reconfiguration. Leaders may facilitate the enlargement or restriction of roles, the latter being a difficult challenge. The leader may foster the negotiation of roles, particularly among medical specialists. The negotiation roles need to be facilitated among physicians and other members of the healthcare team (nurses, pharmacists, technologist, technicians, others), clarifying the relationships between professional autonomy and knowledge of the new technology.

Leadership may strengthen both trends-new technology changes and interprofessional work-by facilitating the development of a shared understanding of each team member's role and their interdependencies. The possible tensions that can emerge between them may be useful to promoting collective opportunities to learn about new technology and encouraging a balance of technological expertise among team members.

Contributors HA made substantial contributions to all aspects of the study and manuscript, including: the design and execution of the study; the analysis and interpretation of the data; theorising the findings and drafting of the paper. $\mathrm{RH}$ made substantial contributions to the interpretation of the analysis, theorising the findings and drafting of the paper. MP made substantial contributions to revising the manuscript. HA, RH and MP have given final approval of the version to be published. Each author should have participated sufficiently in the work to take public responsibility for appropriate portions of the content. HA, RH and MP have agreed to be accountable for all aspects of the work in ensuring that questions related to the accuracy or integrity of any part of the work are appropriately investigated and resolved. 
Funding Funding for this study was provided by the Coordination for the Improvement of Higher Education Personnel, Brazil, for funding this research (National Thesis Award 88887.357373/2019-00).

Competing interests None declared.

Patient consent for publication Not required.

Provenance and peer review Not commissioned; externally peer reviewed.

Data availability statement All data relevant to the study are included in the article or uploaded as supplementary information.

Supplemental material This content has been supplied by the author(s). It has not been vetted by BMJ Publishing Group Limited (BMJ) and may not have been peer-reviewed. Any opinions or recommendations discussed are solely those of the author(s) and are not endorsed by BMJ. BMJ disclaims all liability and responsibility arising from any reliance placed on the content. Where the content includes any translated material, BMJ does not warrant the accuracy and reliability of the translations (including but not limited to local regulations, clinical guidelines, terminology, drug names and drug dosages), and is not responsible for any error and/or omissions arising from translation and adaptation or otherwise.

Open access This is an open access article distributed in accordance with the Creative Commons Attribution Non Commercial (CC BY-NC 4.0) license, which permits others to distribute, remix, adapt, build upon this work non-commercially, and license their derivative works on different terms, provided the original work is properly cited, appropriate credit is given, any changes made indicated, and the use is non-commercial. See: http://creativecommons.org/licenses/by-nc/4.0/.

\section{REFERENCES}

1 Dolic Z, Castro R M. Report on the use of robots and Al in healthcare. Luxembourg, Germany: Policy Department for Economic, Scientific and Quality of Life Policies, 2019.

2 Berlin G, McGinty D, Sherline S. To succeed in a healthcare transformation, focus on organizational health. McKinsey Quarterly, 2019. Available: https://healthcare. mckinsey.com/succeed-healthcare-transformation-focus-organizational-health [Accessed 16 Dec 2019].

3 Cristina P, The Lancet Digital Health. A digital (r)evolution: introducing The Lancet Digital Health. Lancet Digit Health 2019;1:1.

4 Reeves S, Lewin S, Espin S, et al. Interprofessional teamwork for health and social care. Chichester, UK: Wiley-Blackwell, 2010.

5 Brault I, Kilpatrick K, D'Amour D, D'Amour D, et al. Role clarification processes for better integration of nurse practitioners into primary healthcare teams: a multiplecase study. Nurs Res Pract 2014;2014:1-9.

6 Hepp SL, Suter E, Jackson K, et al. Using an interprofessional competency framework to examine collaborative practice. J Interprof Care 2015;29:131-7.

7 Hudson CC, Gauvin S, Tabanfar R, et al. Promotion of role clarification in the health care team challenge. J Interprof Care 2017:31:401-3.

8 Morland C, Pettersen IJ. Translating technological change - implementing technology into a hospital. IJPPM 2018:67:1000-15.

9 Barley SR, Kunda G. Bringing work back in. Organ Sci 2001;12:76-95.

10 Bjørkquist C, Forss M, Samuelsen F. Collaborative challenges in the use of telecare. Scand J Caring Sci 2019;33:93-101.

11 Swinkels ICS, Huygens MWJ, Schoenmakers TM, et al. Lessons learned from a living lab on the broad adoption of eHealth in primary health care. J Med Internet Res 2018;20:e83.

12 Lacasta Tintorer D, Manresa Domínguez JM, Pujol-Rivera E, Tintorer DL, Domínguez $J \mathrm{M}$, et al. Keys to success of a community of clinical practice in primary care: a qualitative evaluation of the ECOPIH project. BMC Fam Pract 2018:19:56.

13 Randell R, Greenhalgh J, Hindmarsh J, et al. Integration of robotic surgery into routine practice and impacts on communication, collaboration, and decision making: a realist process evaluation protocol. Implement Sci 2014;9:52.

14 Beane M. Shadow learning: building robotic surgical skill when Approved means fail. Adm Sci Q 2019;64:87-123.
15 Black LJ, Carlile PR, Repenning NP. A dynamic theory of expertise and occupational boundaries in new technology implementation: Building on Barley's study of CT scanning. Adm Sci Q 2004;49:572-607.

16 Edmondson AC, Bohmer RM, Pisano GP. Disrupted routines: team learning and new technology implementation in hospitals. Adm Sci Q 2001;46:685-716.

17 Barrett M, Oborn E, Orlikowski WJ, et al. Reconfiguring boundary relations: robotic innovations in pharmacy work. Organ Sci 2012;23:1448-66.

18 Gherardi S. Telemedicine: a practice-based approach to technology. Hum Relat 2010;63:501-24

19 Korica M, Molloy E. Making sense of professional identities: stories of medical professionals and new technologies. Hum Relat 2010;63:1879-901.

20 Nicolini D. Stretching out and expanding work practices in time and space: the case of telemedicine. Hum Relat 2007;60:889-920.

21 Segar J, Rogers A, Salisbury C, et al. Roles and identities in transition: boundaries of work and inter-professional relationships at the interface between telehealth and primary care. Health Soc Care Community 2013;21:n/a-13.

22 Gagnon M-P, Lamothe L, Fortin J-P, et al. Telehealth adoption in hospitals: an organisational perspective. J Health Organ Manag 2005;19:32-56.

23 Pelikan HRM, Cheatle A, Jung MF, et al. Operating at a distance - how a teleoperated surgical robot reconfigures teamwork in the operating room. Proc ACM Hum-Comput Interact 2018;2:1-28.

24 Stevens M, Schaik J. Implementing new technologies for complex care: the role of embeddedness factors in team learning. Jrnl of Ops Management 2020;66:112-34.

25 Petrakaki D, Klecun E, Cornford T. Changes in healthcare professional work afforded by technology: the introduction of a national electronic patient record in an English Hospital. Organization 2016:23:206-26.

26 Petrakaki D, Kornelakis A. 'We can only request what's in our protocol': technology and work autonomy in healthcare. New Technol Work Employ 2016:31:223-37.

27 Mathieu-Fritz A, Esterle L, Matthews T. Changes in professional practices during medical teleconsultations. Revue Française de Sociologie 2013;54:303-29.

28 Meyer J, Paré G. The transformative role of telemedicine on coordination: a practice approach. Syst Sci 2017;1:3546-55.

29 Sergeeva A, Huysman M, Faraj S. Transforming work practices of operating room teams: the case of the dA Vinci robot. International Conference on Information Systems, 2015:1-10.

30 Bergey MR, Goldsack JC, Robinson EJ. Invisible work and changing roles: health information technology implementation and reorganization of work practices for the inpatient nursing team. Soc Sci Med 2019;235:112387-8

31 Barley SR. Technology as an occasion for structuring: evidence from observations of CT scanners and the social order of radiology departments. Adm Sci Q 1986:31:78-108.

32 Burri RV. Doing distinctions: boundary work and symbolic capital in radiology. Soc Stud Sci 2008:38:35-62.

33 Huising R. To hive or to hold? producing professional authority through scut work. Administrative Science Quarterly 2015;60:263-99.

34 Dopson S, Annabelle M. Leading health care organizations. Basingstoke: Palgrave Macmillan, 2003

35 Braverman H. Labor and monopoly capital. Mon Rev 1974;26:1.

36 Dychtwald K, Erickson T, Morison B. It's time to retire. retirement. Harv Bus Rev 2004:82:48-57.

37 Rigby D. Look before you lay off. Harv Bus Rev 2002;80:1-2.

38 Mikhailova 0 . Adoption and implementation of new technologies in hospitals: a network perspective. IMP 2018;12:368-91.

39 Rogers EM. Diffusion of innovations. New York: Free Press, 2003.

40 Christensen CM, Bohmer R, Kenagy J. Will disruptive innovations cure health care? Harv Bus Rev 2003;78:102-12.

41 Bezemer T, de Groot MC, Blasse E, et al. A human (e) factor in clinical decision support systems. J Med Internet Res 2019:21:e11732-41.

42 Hossain A, Quaresma R, Rahman H. Investigating factors influencing the physicians' adoption of electronic health record (EHR) in healthcare system of Bangladesh: An empirical study. Int J Inf Manage 2019;44:76-87. 